\title{
Pengukuran Koefisien Ábsorbsi Bunyi pada Serbuk Gergaji Kayu Nyatoh (Palaquium species) sebagai Bahan Peredam
}

\author{
Rizky Kurniawan Imbana* ${ }^{*}$ As'aria, Seni Herlina J. Tongkukuta \\ aJurusan Fisika, FMIPA, Unsrat, Manado
}

KATA K U N C I

Intensitas awal (I0)

Intensitas transmisi $\left(I_{T}\right)$

Intensitas refleksi $\left(I_{R}\right)$

\section{A B S T R A K}

Telah dilakukan penelitian untuk memperoleh nilai koefisien absorbsi bunyi pada papan partikel dari bahan campuran serbuk gergajian kayu nyatoh dan tepung kanji dengan variasi ukuran butir. Papan partikel dibuat dengan komposisi $50 \mathrm{~g}$ serbuk gergaji dan $50 \mathrm{~g}$ tepung kanji. Papan partikel dibuat dengan rapat massa $(\rho)=0,62 \times 10^{3} \mathrm{~kg} \cdot \mathrm{m}^{-3}$. Koefisien absorbsi bunyi diukur dengan menggunakan sound level meter, intensitas bunyi yang diukur antara lain intensitas bunyi yang datang, intensitas yang dipantulkan dan intensitas yang ditransmisikan. Intensitas absorbsi didapat dengan mengurangkan intensitas awal $\left(I_{0}\right)$ dengan intensitas transmisi $\left(I_{T}\right)$ dan intensitas refleksi $\left(I_{R}\right)$. Data yang diperoleh dibuat grafik dan dianalisis. Diperoleh hasil bahwa papan partikel yang terbuat dari campuran serbuk gergajian kayu nyatoh dan tepung kanji dengan komposisi 1:1 (sampel 3) adalah papan partikel terbaik sebagai bahan absorbsi bunyi pada penelitian ini. Papan partikel mempunyai sifat fisis: koefisien absorbsi $0,15 \mathrm{~cm}^{-1}$, intensitas refleksi $1,5 \mathrm{~dB}$, intensitas absorbsi 29,45 dB dan efisiensi absorbsi 29,42 \%.

\begin{tabular}{l}
\hline K E Y W O R D S \\
\hline Initial intensity $\left(I_{O}\right)$ \\
Transmission intensity $\left(I_{T}\right)$ \\
Reflection intensity $\left(I_{R}\right)$
\end{tabular}

A B S T R A C T
Research has been conducted to obtain the sound absorbtion
coefficient of the particle board from the mixture of the sawdust of Nyatoh
and the starch with the variation of the grain size. Particle board is made
with the composition of $50 \mathrm{~g}$ sawdust and $50 \mathrm{~g}$ starch. Particle board is
made with the mass density $(\rho)=0.62 \times 10^{3} \mathrm{~kg} \cdot \mathrm{m}^{-3}$. Sound absorbtion
coefficient is measured using a sound level meter, sound intensity is
measured such as the intensity of incident sound, the intensity of reflected
sound and the intensity of transmitted sound. The intensity of absorbtion
is obtained by reducing the initial intensity (IO) with the transmission
intensity (IT) and the reflection intensity $\left(I_{R}\right)$. The obtained data were
graphed and analyzed. The results indicated that the particle board that is
made from the mixture of the sawdust of Nyatoh and the starch with the
composition $1: 1$ (sample 3 ) is the best particle board as sound absorbtion
material in this research. The particle board has physical properties: the
absorbtion coefficient $0.15 \mathrm{~cm}-1$, the reflection intensity $1.5 \mathrm{~dB}$, the
absorbtion intensity $29.45 \mathrm{~dB}$, and the absorbtion efficiency $29.42 \%$.

AVAILABLE ONLINE

25 Februari 2014

\section{Pendahuluan}

Kebisingan dewasa ini sangat mengganggu, tetapi jika masih dalam batas toleransi biasanya banyak yang tidak memperdulikan. Bising mempunyai efek kurang baik pada kesehatan manusia. Pengendalian bising bukan hanya meredam sumber bising, membuat penghalang, tetapi memakai material peredam. Dalam bidang teknologi tepat guna, memanfaatkan limbah hasil hutan merupakan salah satu cara untuk memaksimalkan sumber daya alam yang tersedia

*Corresponding author: Jurusan Fisika FMIPA UNSRAT, Jl. Kampus Unsrat, Manado, Indonesia 95115; Email address: rizky0704@gmail.com 
sehingga dapat bermanfaat bagi kehidupan manusia.

Limbah industri yang digunakan dalam penelitian tugas akhir ini adalah limbah serbuk gergajian yang jumlahnya sekitar $3.500 \mathrm{~m}^{3} \mathrm{di}$ Sulawesi Utara (BPS, 2010). Koefisien absorbsi merupakan salah satu parameter penting dalam penentuan sejauh mana suatu bahan dapat menyerap dan mereduksi bunyi.

Harga koefisien absorbsi $(\alpha)$ berkisar dari 0 sampai 1 . Jika $\alpha$ bernilai 0 , artinya tidak ada bunyi yang diabsorbsi. Sedangkan jika $\alpha$ bernilai 1 , artinya $100 \%$ bunyi yang diabsorbsi oleh bahan dan nilai koefisien absorbsi 1 menyatakan absorbsi yang sempurna (Sriwigiyatno, 2006).

Koizumi et al. (2002), telah mengembangkan bahan peredam bunyi dari serat bambu yang mutunya bisa sebagus glasswool. Lee dan Joo (2003), telah mengembangkan peredam bunyi dari serat polyester daur ulang. Yang et al. (2004), telah melakukan penelitian tentang penggunaan jerami untuk campuran bahan bangunan yang bisa meningkatkan penyerapan bunyi. Jika ditilik lebih mendalam benda-benda di sekeliling yang tampak kurang berguna, ada yang dapat dimanfaatkan sebagai peredam bunyi.

\section{Metode}

Bahan penelitian adalah limbah dari penggergajian kayu hasil hutan, limbah berupa serbuk gergajian kayu nyatoh, bahan tersebut terdapat dalam jumlah yang melimpah, murah, dan renewable, ini juga sebagai biomassa dan bahan berlignoselulosa serta tepung kanji yang berfungsi sebagai perekat serbuk gergajian. Diagram Alir penelitian ini ditunjukkan pada Gambar 1.



Gambar 1. Diagram Alir Penelitian

\section{Hasil dan Pembahasan}

\subsection{Pembuatan Papan Partikel}

Papan partikel dibuat dengan tebal $2,5 \mathrm{~cm}$ dan rapat massa $(\rho)=0,62 \times 10^{3} \mathrm{~kg} \cdot \mathrm{m}^{-3}$ (Makalalag, 2011). Setelah bahan dicetak dalam wadah pipa dengan alat press, belum menjadi papan partikel yang sempurna karena kadar air masih tinggi. Kadar air papan partikel dihilangkan dengan cara yang sama pada semua sampel, yaitu metode pengeringan. Sampel dikeringkan di bawah panas sinar matahari selama 3 hari. Massa sampel setelah pengeringan sama dengan massa sampel awal tanpa air (sebelum penyemprotan).

\subsection{Koefisien Absorpsi Bunyi}

Bunyi dari sumber bunyi yang dikenakan pada sebuah penghalang (papan partikel) akan mengalami proses: refleksi, absorbsi, dan transmisi. Nilai koefisien absorbsi $(\alpha)$ diperoleh dengan menggunakan persamaan:

$$
\alpha=-\frac{1}{x} \ln \frac{I}{I_{0}}
$$

Setelah dilakukan perhitungan pada hasil pengukuran intensitas diperoleh grafik koefisien absorbsi.



Gambar 2. Grafik Koefisien Absorbsi Bunyi Bahan terhadap Intensitas Awal (Io)

Gambar 2 menyatakan grafik koefisien absorbsi bunyi terhadap intensitas awal $\left(I_{o}\right)$ pada setiap sampel berbeda-beda. Pada intensitas 91.1 $\mathrm{dB}-107,2 \mathrm{~dB}$ semua sampel relatif mempunyai $\alpha$ yang meningkat. Terdapat beberapa sampel yang mempunyai $\alpha$ yang cukup tinggi yaitu sampel 3, 4 dan 5. Naik dan turunnya koefisien absorbsi bunyi terhadap perubahan intensitas awal (IO) diduga disebabkan oleh frekuensi gelombang bunyi yang datang berlawanan dengan frekuensi dari papan partikel. Jika frekuensi gelombang bunyi yang datang sama dengan frekuensi dari papan partikel maka akan terjadi interferensi saling menguatkan sehingga terjadi absorbsi bunyi yang rendah. Sebaliknya jika frekuensi gelombang bunyi yang datang tidak sama dengan frekuensi dari papan partikel maka akan terjadi pelemahan terhadap gelombang bunyi yang datang, hal ini yang menyebabkan koefisien absorbsi bunyi menjadi tinggi. 
Hasil uji statistik terhadap semua sampel memperlihatkan bahwa sampel 3 mempunyai nilai koefisien absorbsi rata-rata yang tertinggi $\left(\alpha_{3}=0,15\right.$ $\mathrm{cm}^{-1}$ )

\subsection{Intensitas Refleksi $\left(I_{R}\right)$ Bunyi}

Intensitas bunyi yang terukur di ruangan di depan sampel adalah intensitas gabungan antara intensitas yang direfleksikan $\left(I_{R}\right)$ dengan intensitas awal $\left(I_{0}\right)$. Intensitas refleksi bunyi diperoleh dengan mengurangi intensitas bunyi yang terukur di depan sampel $\left(I_{R^{\prime}}\right)$ dengan intensitas awal $\left(I_{0}\right)$ dituliskan:

$$
I_{R}=I_{R^{\prime}}-I_{0}
$$

Perilaku intensitas refleksi $\left(I_{R}\right)$ pada setiap sampel terhadap perubahan intensitas awal (Io) dapat dilihat pada Gambar 3.



Gambar 3. Grafik Intensitas Awal (IO) terhadap Intensitas Refleksi $\left(I_{R}\right)$.

Grafik pada Gambar 3 ternyata tidak memberikan kecenderungan yang sama terhadap intensitas yang direfleksikan dari tiap sampel. Sampel 3 memiliki intensitas refleksi yang paling rendah. Semakin besar nilai intensitas yang direfleksikan suatu bahan, maka bahan tersebut semakin bersifat memantulkan dan semakin tidak baik sebagai bahan peredam, sebaliknya semakin kecil intensitas bunyi yang direfleksikan, maka semakin baik untuk bahan peredam.

Hasil uji statistik memperlihatkan bahwa sampel 3 mempunyai intensitas refleksi yang paling kecil yaitu $\left(I_{R} 3=1,5 \mathrm{~dB}\right)$.

\subsection{Intensitas Absorpsi Bunyi}

Intensitas absorbsi merupakan intensitas yang diabsorbsi oleh bahan. Intensitas ini merupakan hasil perhitungan, intensitas absorbsi didapat dengan mengurangkan intensitas awal $\left(I_{0}\right)$ dengan intensitas transmisi $\left(I_{T}\right)$ dan intensitas refleksi $\left(I_{R}\right)$, dengan persamaan:

$$
l_{a b s o r b s i}=I_{O}-I_{T}-I_{R}
$$

Intensitas absorbsi berguna untuk mengetahui seberapa besar intensitas bunyi yang mampu diabsorbsi oleh bahan. Sehingga bahan berkualitas yang baik adalah bahan yang mempunyai intensitas absorbsi yang besar.

Setelah dilakukan perhitungan pada hasil pengukuran intensitas diperoleh grafik intensitas absorbsi (Gambar 4).

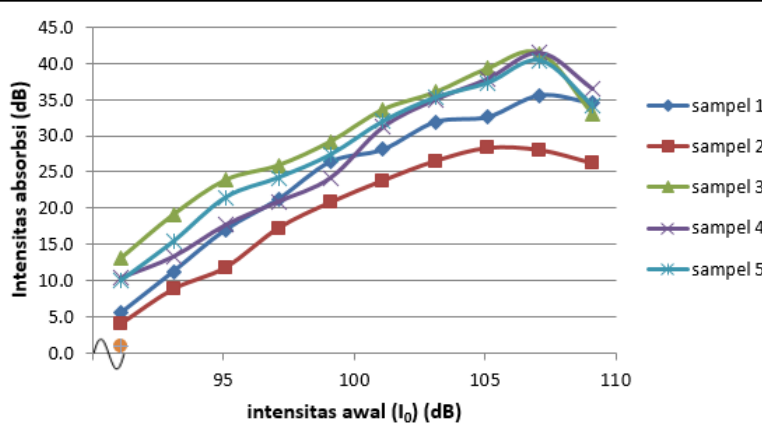

Gambar 4. Grafik Intensitas Absorbsi Setiap Sampel.

Hasil uji statistik menunjukkan sampel 3 mempunyai intensitas absorbsi paling besar yaitu 29,45 dB, sehingga dapat dikatakan bahwa sampel 3 adalah sampel dengan kualitas absorbsi terbaik diantara kelima sampel.

\subsection{Efisiensi Absorbsi (n) Bunyi}

Efisiensi absorbsi digunakan untuk mengetahui berapa persentase intensitas bunyi yang diabsorbsi oleh bahan. Efisiensi absorbsi $(\eta)$ dihitung dengan rumus:

$$
\eta=\frac{I_{a b s o r b s i}}{I_{0}-I_{R}} \times 100 \%
$$

Hasil perhitungan efisiensi absorbsi $(\eta)$ dapat dilihat pada Gambar 5.

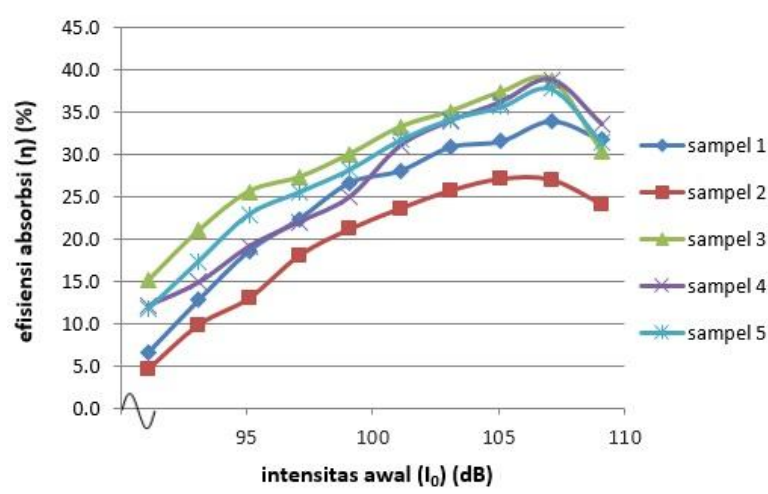

Gambar 5. Grafik Persentase Efisiensi Absorbsi Setiap Sampel

Hasil uji statistik menunjukkan bahwa sampel 3 memiliki efisiensi absorbsi terbaik dengan nilai $29,42 \%$.

\subsection{Analisis Absorbsi Bahan}

Analisis koefisien absorbsi bunyi menyatakan bahwa sampel 3 yang mempunyai komposisi $50 \mathrm{gr}$ serbuk gergajian dan $50 \mathrm{gr}$ tepung kanji, butir berukuran 303 mesh memiliki koefisien absorbsi paling baik dengan $\left(\alpha=0,15 \mathrm{~cm}^{-1}\right)$. Kualitas absorbsi terbaik ini meliputi: intensitas refleksi, intensitas absorbsi, dan efisiensi absorbsi bunyi. Intensitas refleksi sampel 3 cukup rendah yaitu $\left(I_{R}=\right.$ $1,5 \mathrm{~dB}$ ), intensitas absorbsi yang cukup besar yaitu (labsorbsi $=29,45 \mathrm{~dB}$ ), dan efisiensi absorbsi bunyi cukup efisien yaitu $(\eta=29,42 \%)$. 
Karakteristik papan partikel yang baik sebagai bahan peredam adalah papan partikel yang memiliki intensitas refleksi kecil, intensitas absorbsi besar, dan efisiensi absorbsi bunyi yang cukup besar. Karakteristik ini dimiliki oleh papan pertikel pada sampel 3 dengan nilai-nilai : $\left(\alpha=0,15 \mathrm{~cm}^{-1}\right)$, $\left(I_{R}=1,5 \mathrm{~dB}\right),\left(l_{\text {absorbsi }}=29,45 \mathrm{~dB}\right)$, dan $(\eta=29,42$ \%). Daya absorbsi dari papan partikel tidak bergantung secara linier terhadap ukuran butir tetapi pada ukuran butir tertentu kemampuan redamannya bisa tinggi.

\section{Kesimpulan}

Papan partikel yang terbuat dari campuran serbuk gergajian kayu nyatoh dan tepung kanji dengan komposisi 1:1 (sampel 3), serta besar butiran dari saringan berukuran 303 mesh adalah papan partikel yang terbaik sebagai bahan absorbsi bunyi pada penelitian ini. Papan partikel mempunyai sifat fisis: koefisien absorbsi $\left(\alpha=0,15 \mathrm{~cm}^{-1}\right)$, intensitas refleksi $\left(I_{R}=1,5 \mathrm{~dB}\right)$, intensitas absorbsi $\left(l_{\text {absorbsi }}=29,45 \mathrm{~dB}\right)$, dan efisiensi absorbsi $(\eta=$ $29,42 \%)$.

\section{Daftar Pustaka}

1] Badan Pusat Statistik. 2010. Laporan Produksi Industri Kehutanan. Jakarta.
2] Koizumi, T., N. Tsujiuchi, and A. Adachi. 2002. The Development of Sound Absorbing Materials Using Natural Bamboo Fibers. WIT Press. Southhampton.

3] Lee, Y., and C. Joo. 2003. Sound Absorbtion Properties of Recycled Polyester Fibrous Assembly Absorbers. Autex Res. J, 3(2). 2003.

4] Makalalag, A. 2011. Pengukuran Koefisien Absorbsi Bunyi Pada Campuran Serbuk Daging Sabut Kelapa dan Serbuk Sekam Padi sebagai Bahan Peredam [skripsi]. FMIPA UNSRAT. Manado.

5] Sriwigiyatno. 2006. Analisis Pengaruh Kolom Udara Terhadap Nilai Koefisien Absorpsi Bunyi pada Dinding Partisi Menggunakan Metode Tabung Impedansi Dua Mikrofon [skripsi]. Jurusan Fisika F-MIPA UNS. Surakarta.

6] Yang, H.S., Y.K. Lee, H.J. Kim, and J.Y. Jeon. 2004. Possibility of using Waste Tire Composites Reinforced with Rice Straw as Construction Materials. J. Bioresour Technol. 95(1):61-65. 